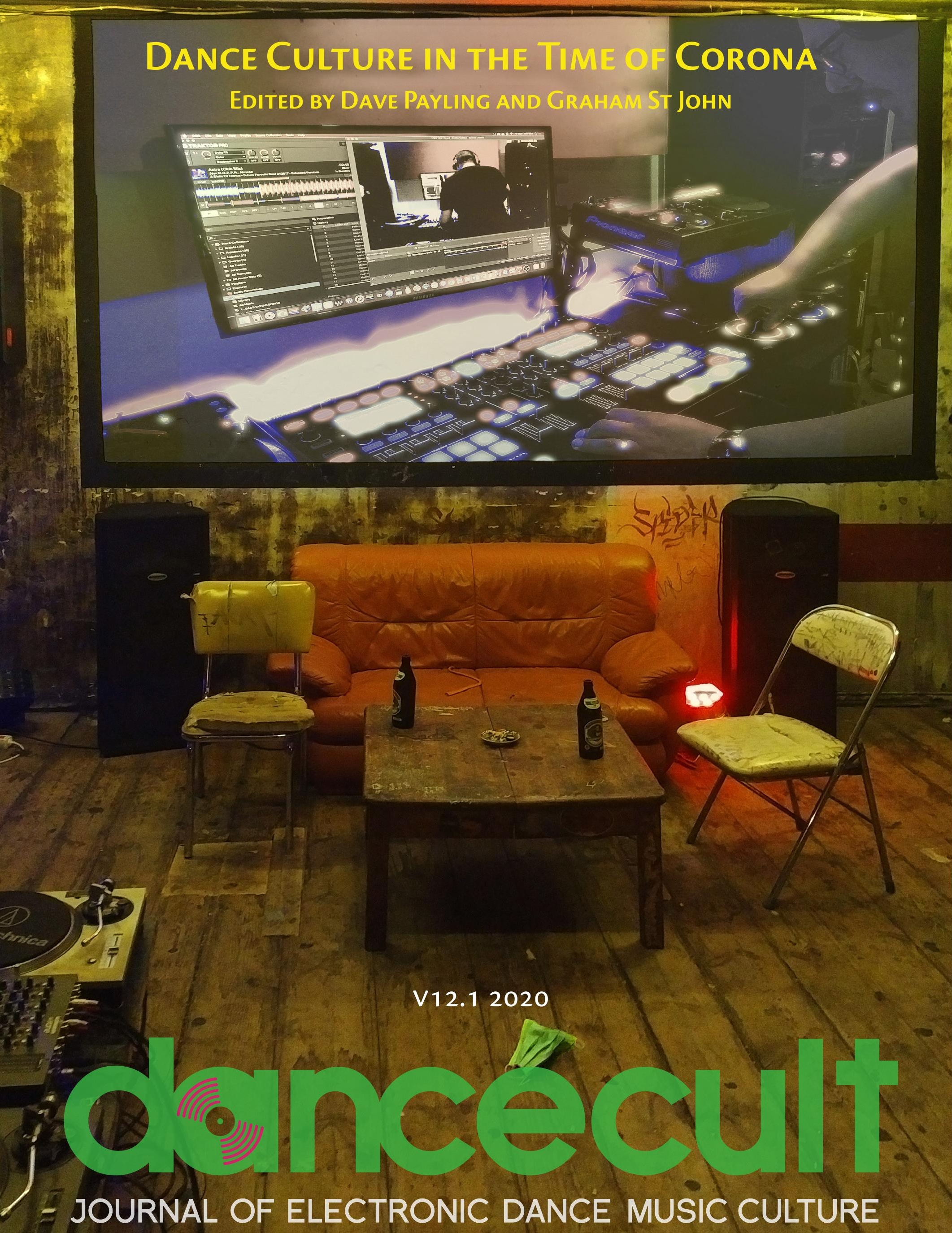




\section{DANCECULT}

JoURNAL OF ELECTRONIC

DANCE Music Culture

Issue 12(1) 2020

ISSN 1947-5403

(C2020 Dancecult

Published yearly at $<$ http://dj.dancecult.net $>$

EXECUTIVE EDITOR

Graham St JOHN (AU)

PRODUCTION EDITOR

BOTOND VITOS (DE)

FROM THE FLOOR EDITORIAL DIRECTOR

Dave Payling

(STAFFORDSHIRE UNIVERSITY, UK

FROM THE FLOOR EDITOR

Alice O'Grady

(UNIVERSITY OF LEEDS, UK)

REVIEWS EDITOR

TOBY YOUNG

(UNIVERSITY OF OXFORD, UK)

OPERATIONS DIRECTOR

BOTOND VITOS (DE)

MANAGING EDITOR

TOMmy COLTON SyMmes

(RICE UNIVERSITY, US)

COMMUNITY MANAGER

KATRINA LOUGHREY (DE)

ART DIRECTOR

BOTOND VITOS (DE)

ASSOCIATE EDITORS

KATH O'DONNELL (AU)

Alistair Fraser

(MAYNOOTH UNIVERSITY, IE)

PRODUCTION ASSISTANTS

RICHARD ANDERSON

(UNIVERSITY OF LIVERPOOL, UK)

Christopher Charles

(UNIVERSITY OF BRISTOL, UK)

Dave Payling

(STAFFORDSHIRE UNIVERSITY, UK)
Dancecult: Journal of Electronic Dance Music Culture is a peer-reviewed, open-access e-journal for the study of electronic dance music culture (EDMC). Launched in 2009, as a platform for interdisciplinary scholarship on the shifting terrain of EDMCs worldwide, Dancecult houses research exploring the sites, technologies, sounds and cultures of electronic music in historical and contemporary perspectives. Playing host to studies of emergent forms of electronic music production, performance, distribution, and reception, as a portal for cutting-edge research on the relation between bodies, technologies, and cyberspace, as a medium through which the cultural politics of dance is critically investigated, and as a venue for innovative multimedia projects, Dancecult is the leading venue for research on EDMC.

\section{Cover Design and Photography by Botond Vitos and Dave Payling \\ THANKS TO LOOPHOLE BERLIN FOR PROVIDING THE SPACE}

\section{INTERNATIONAL ADVISORY BOARD}

Sean Albiez (SOUthampton Solent University, UK), Anthony D'Andrea (UNIVERSITY OF LIMERICK, IE), Mark J Butler (NORTHWESTERN UNIVERSITY, US), Rebekah Farrugia (OAKLAND UnIVERSITY, US), Kai Fikentscher (DE), Alistair Fraser (MAYNOOTH UNIVERSITY, IE), Luis-Manuel Garcia (University of Birmingham, UK), Anna Gavanas (INSTITUTE FOR FUtURES Studies, SE), Ross Harley (University of New South Wales, AU), Tim Lawrence (UNIVERSITY OF EAST LONDON, UK), Geert Lovink (UNIVERSITY OF Amsterdam, NL), Alejandro L. Madrid (University of IlLINoIs, ChICAGo, US), Paolo Magaudda (University of PAdova, IT), Charity Marsh (UNIVERSITY OF Regina, CA), Andrew Murphie (University of New South Wales, AU), Alice O'Grady (University of LeEds, United KInGdom), Christopher Partridge (LanCaster University, UK), Dave Payling (StafFordshire University, UK), Anne Petiau (ITSRS / Université ParIS 5, FR), Hillegonda C Rietveld (London SOUth BANK UNIVERSITY, UK), Geoff Stahl (VICTORIA UNIVERSITY OF WELLINGTON, NZ), Sonjah Nadine Stanley-Niaah (UNIVERSITY OF WeSt INDIES, JM), Graham St John (AU), Jonathan Sterne (MCGILL UNIVERSITY, CA), Will Straw (MCGILl University, CA), Rupert Till (University of HudDeRSFIELD, UK), BOtOND Vitos (DE), TOBY YOUNG (UNIVERSITY OF OXFord, UK) 


\section{dencecult \\ JOURNAL OF ELECTRONIC DANCE MUSIC CULTURE \\ ISSN 1947-5403 @2020 Dancecult http://dj.dancecult.net}

V12.12020

Editor's Introduction: Dance Culture in the Time of Corona $\ldots \ldots \ldots \ldots \ldots \ldots \ldots \ldots \ldots$ DaVe PAYLING AND GRAHAM ST JOHN

\section{FROM THE FLOOR - ONLINE}

No Screenshots on the Dance Floor

BEN ASSITER

India's Electronic Music Scene Under Lockdown: The First Three Months of the COVID-19 Pandemic CHRIS MCGUINNESS

A Post-Post-Soviet Scene Post-Quarantine

CAMILLE LeBLANC LieDERMAN

Virtual Dance Floors: Shall We Dance or Fly?

EMÍlIa SIMÃo AND PAULA GuerRa

Good Vibes Friday: Reflections on Livestreaming During the COVID-19 Lockdown

SAMANTHA WARREN

Sound Systems at the George Floyd Protests in Minneapolis During the Summer of 2020

TOMMY SYMMES

Transformation Through Connection? Insights From a Pilot Study of Story Sharing Cubes at Burning Man Events TERJE TOOMISTU AND JUKKA-PEKKÄ HEIKKILÄ

\section{FEATURE ARTICLES}

Bring the Break-Beat Back! Authenticity and the Politics of Rhythm in Drum ' $n$ ' Bass . . . . . . . 3 CHRIS CHRISTODOULOU

Genre in Practice: Categories, Metadata and Music-Making in Psytrance Culture . . . . . . . . . . . . . 22 Christopher ChARLES

The Studio as Contemporary Autonomous Zone: Crisis and Creativity in Electronic Music . . . . . . . . 48 PAUL ChAmbers

The Vibe as Peace: EDMC Conflict Studies and Montreal Psytrance Spheres . . . . . . . . . . . . . 66 Marc-Olivier CASTAGner

\section{REVIEWS}

Bass, Mids, Tops: An Oral History of Sound System Culture (Joe Muggs \& Brian David Stevens) ․ . . . . .85 EDWARD K. SPENCER

Night Fever: Designing Club Culture 1960 - Today (Mateo Kries, Jochen Eisenbrand \& Catherine Rossi, eds.) \&

This Must Be the Place: An Architectural History of Popular Music Performance Venues (Robert Kronenburg). . 89 HILLEGONDA C. RIETVELD

Moon Juice Stomper: A Novel (Goa 1987-96) (Ray Castle) . . . . . . . . . . . . . . . . . . . . . . .92 GRAHAM ST JOHN

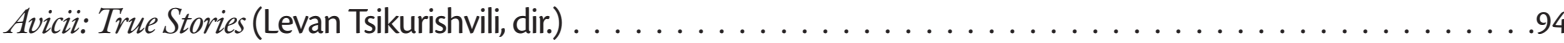
George MusGrave 


\title{
Dance Culture in the Time of Corona
}

\author{
EDITOR'S INTRODUCTION
}

Produced during the Great Confinement of 2020, this issue of Dancecult features a special From the Floor edition (Dance Culture in the Time of Corona) alongside regular feature articles. The world navigates a pandemic in full rage. Inside the networked and mediated immediacy of global-scale surreality, dance music cultures and industries are adversely impacted. Passing into an extended moment of global uncertainty, our distributed eventcentred communities show little sign of returning to "normal". Documenting their author's thoughts and experiences during the first few months of the COVID-19 crisis, when the first wave of infections and lockdowns spread across the planet, the articles in From the Floor 2020 echo this uncertainty.

The introduction of measures to reduce and prevent travel and contact has decreased opportunities for people to socialise and halted larger gatherings leading to major international festivals, concerts, club nights, carnivals and conferences being cancelled or transformed to virtual gatherings. This is particularly disruptive for our community which relies on these events for connection and transformation (see Toomistu and Heikkilä this issue). Venues and musicians have also been hit financially, leaving many clubs on the brink of closure (Hancock and Gray 2020), musicians seeking ways to supplement their income (see McGuinness this issue) and party people without the charged feelings of solidarity (Vandenberg, Berghman and Schaap 2020).

Undeterred and with limited options, DJs and producers have made efforts to continue their work. This has led to an upsurge in the adoption of streaming technologies, with smaller pop-up events run by individuals and large scale planned events promoted by established companies and organisations (see Assiter this issue). The DiY ethos inherent to the scene, re-emerges. Piecing together the required equipment, finding space and promoting online events virtually has become an urgent necessity (see Warren this issue). These efforts have provided options for real-time connections and feedback between artists and their audience, and ravers can instant message and chat with each other, conjuring some degree of the vibe that occurs so naturally in person. This collective effervescence has been recreated using emojis and instant messages to livestream chats and potentially more effectively through immersion in the virtual worlds available on some platforms (see Simao and Guerra this issue). Doors have therefore been opened for many to develop and continue these strategies into the future.

These efforts have helped fill the void, but they exclude those without the necessary technologies or bandwidth and are insufficient in creating the visceral experience felt in the crowd and lifted by the energy emanating from the speaker stacks of a good sound system. A few "real" events have continued for those willing to take the risk, sometimes expected and others less predictable. Coronavirus couldn't prevent large gatherings and sound systems

\footnotetext{
Dancecult: Journal of Electronic Dance Music Culture 12(1): 1-2 ISSN 1947-5403 @2020 Dancecult http://dj.dancecult.net http://dx.doi.org/10.12801/1947-5403.2020.12.01.00 
at the recent protests in Minneapolis (see Symmes this issue). Many others have sought the release valve of free parties and other unlicensed raves (Lhooq 2020). While openly promoted initially, as news outlets condemned their occurrence, and authorities responded with the threat of significant fines, events were pushed further underground.

As the content of From the Floor 2020 illustrates, the EDMC research community responded with enthusiasm and at short notice to the call on this theme at this critical time. We expect our next editions to feature further content addressing the pandemic's impact across EDMCs and research, and encourage further submissions (to both our Feature article and From the Floor sections). In addition to regular feature articles, we trust readers will enjoy the following From the Floor content:

- Ben Assiter (UK), No Screenshots on the Dance Floor.

- Camille LeBlanc Liederman (Lithuania), A Post-Post-Soviet Scene Post-Quarantine.

- Chris McGuinness (US), India's Electronic Music Scene Under Lockdown: the First Three Months of the COVID-19 Pandemic.

- Emília Simão and Paula Guerra (Portugal), Virtual Dance Floors: Shall We Dance or Fly?

- Samantha Warren (UK), Good Vibes Friday: Reflections on Livestreaming During the Lockdown.

- Tommy Symmes (US), Sound Systems at the George Floyd Protests in Minneapolis During the Summer of 2020.

- Terje Toomistu (Estonia) and Jukka-Pekkä Heikkilä (Finland), Transformation Through Connection? Story Sharing Cubes at Burning Man Events

While the "other side" remains opaque inside our unevenly distributed global meltdown, as the material presented in this issue of Dancecult illustrates, optimism and community remain vital across electronic dance and music cultures.

Until we meet again on the dance floor...

Dave Payling (From the Floor Section Director)

Graham St John (Executive Editor)

Dancecult: Journal of Electronic Dance Music Culture

\section{REFERENCES}

Hancock, Alice, and Alistair Gray. 2020. "Nightclubs Fear Collapse as Dance Floors Remain Out of Bounds". Financial Times. 19 September. $<$ https://www.ft.com/content/3b1535f3-478b4bd1-a1e4-613ef675e12f>. (accessed 16 October 2020).

Lhooq, Michelle. 2020. "Rave to the Grave". Rave New World. 18 September.

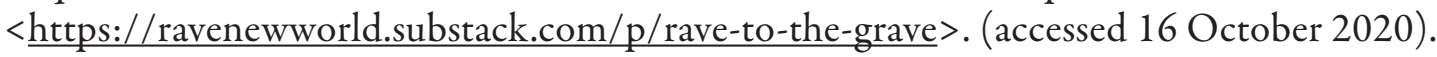

Vandenberg, Femke, Michaël Berghman and Julian Schaap. 2020. “The 'Lonely Raver': Music Livestreams During COVID-19 as a Hotline to Collective Consciousness?”. European Societies. $<$ https://doi.org/10.1080/14616696.2020.1818271>. 